\title{
Anaesthesia for major vascular surgery
}

The objectives of this Refresher Course review are: (1) to present historical and current information regarding the preoperative evaluation and risk assessment of patients scheduled to undergo major vascular surgery; (2) review certain essential aspects of the physiology and pathophysiology of aortic cross clamping; and (3) to summarize information regarding the efficacy of comparative anaesthetic techniques for these procedures.

\section{Perioperative evaluation, risk assessment and modification}

Since patients undergoing major vascular surgery usually suffer from atherosclerotic pathology, most will have overt or occult manifestations of vascular disease in several organ systems. The classic study of Hertzer et al. ${ }^{1}$ demonstrated that a very high proportion of patients undergoing aortic surgery had at least one critical coronary artery stenosis. General acceptance of this fact has given rise to a wide spectrum of clinical practice with respect to the degree and nature of preoperative testing in this patient population. The last decade has witnessed much investigational activity toward evaluation of preoperative tests (Dipyridamole-Thallium, ambulatory ECG, stress ECHO, etc.) that identify patients at risk for perioperative cardiac morbidity and mortality, with the highest degree of sensitivity and specificity. Conversely, little work has been directed toward the much more difficult issue of establishing the appropriate sequence of work-up or treatment to minimize or reduce the determined risk. Risk assessment will have value only if it leads to risk modification, or otherwise influences the decisions regarding surgical or anaesthetic procedures. Very recent work has begun to put this matter on a rational basis. Fleisher $e t$ al. ${ }^{2}$ have published a Decision Analysis approach to direct procedures and therapy, before abdominal aortic aneurysm surgery. They show that the decision to conduct particular tests (potentially leading to coronary artery surgery or other therapy before vascular surgery) depends on several elements of morbidity and mortality data which must be specific to the institution. These include: (1) the baseline cardiac mortality for abdominal aortic aneurysm surgery; (2) the mortality for coronary revascularization; (3) the cardiac mortality related to aneurysm surgery in patients who have undergone coronary revascularization; (4) the probability of coronary artery disease in patients with particular symptomatology; (5) the cardiac mortality related to aneurysm surgery in patients with significant uncorrected coronary artery disease; (6) the mortality from coronary angiography; (7) the cardiac mortality related to abdominal aneurysm surgery if no testing or revascularization is performed; and (8) the sensitivity and specificity of the test in question. Since these numbers undoubtedly vary from institution to institution, and even within the same institution at different times or between different teams, the actual performance of specific testing procedures is multifactorial.

For institutions whose cardiac mortality, related to aneurysm surgery in patients with significant uncorrected coronary artery disease, is less than $7.5 \%$, preoperative testing will not result in improved outcome regardless of the probability of coronary artery disease in the population. This is very important news for two reasons: (1) a systematic implementation of these findings will result in a considerable decrease in testing and, thus, in overall hospital costs and, (2) it demonstrates the farreaching importance of the details of perioperative management, which may positively influence overall morbidity.

It is well to consider the issue of monitoring modalities which may influence outcome. All patients undergoing aortic surgery should have continuous intravascular monitoring of arterial pressure. Although some clinicians advocate the use of pulmonary artery (PA) catheters in all patients undergoing aortic cross clamp procedures, others base the decision on cross clamp level and extent of ancillary disease. A rational approach is to use a PA catheter in those cases requiring a suprarenal (or above) cross clamp, and reserve its use in infrarenal aneurysms and occlusive disease to those with significant cardiac, renal or pulmonary pathology. Certainly, the rapid large changes in loading conditions that occur during aneurysm surgery, and the problems of fluid mobilization and renal dysfunction postoperatively, combine to make pulmonary artery catheters helpful in all but the healthiest patients. This endorsement presumes that invasive monitoring is initiated safely; the

From the Department of Anesthesiology \& Critical Care, Vanderbilt University, Suite 2301, TVC, 1121, 21 st Avenue South, Nashville, Tennessee, USA 37232-2125. 
pressure transducers are properly leveled, zeroed, and calibrated; cardiac outputs are technically sound; calculated and measured variables are interpreted correctly; and therapeutic interventions reflect appropriate understanding of physiology and pharmacology. If any one of these requirements is missing, PA catheterization is best omitted. Because effective and appropriate use of the information obtained from PA catheterization is completely dependent upon all these factors, it has proved almost impossible to establish unequivocally the value of this modality in patient care. For those who develop the necessary expertise, it is a powerful tool.

The importance of assuring adequate organ profusion throughout the perioperative period, in reducing morbidity and mortality is assumed, but unproved. Current principles suggest that anaesthesia goals should include attenuation or ablation of the surgical stress response. The beneficial effects of reduction of the stress response include less perioperative hypercoagulability, preservation of immune function, and a probably lower incidence of myocardial ischaemia.

\section{Physiology and pathophysiology of aortic cross clamping}

The haemodynamic and metabolic alterations caused by acute interruption of aortic blood flow include changes in arterial blood pressure, cardiac function, myocardial perfusion, and acid-base status, as well as tissue integrity of the kidneys, viscera, and spinal cord.

\section{Blood pressure}

The degree of hypertension caused by application of an aortic cross-clamp depends on the location of the clamp, the degree of collateralization, and the pre-occlusion aortic flow. Thus, an infrarenal clamp in a patient with aortic occlusive disease may cause virtually no elevation in the blood pressure because pre-clamp flow was nil. Clamping below the renal arteries is the most common clinical circumstance and usually produces only a small increase in blood pressure, while supracoeliac occlusion can result in prodigious hypertension.

\section{Venous return and cardiac output}

Although it may seem intuitive that cardiac output should decrease with acute occlusion of a major arterial conduit caused by an increase in resistance, there are levels of physiological complexity involving reflex mechanisms, venous return, and left heart function that modify this expectation. To illustrate the issues, consider first that both the arterial outflow and the venous return serving the sub-diaphragmatic circulation are simultaneously occluded (that is, both the descending thoracic aorta and the inferior vena cava are clamped).
The cardiac output would immediately decrease by half since half of the venous return has been eliminated. Meanwhile, the arterial bed has only half the number of vessels to accept flow, and its resistance to flow will double. The net result of half the cardiac output flowing into twice the resistance is an unchanged blood pressure. In this scenario, the stroke volume and stroke work are also halved. This illustrates a major point about directional changes in haemodynamic variables during aortic cross clamping - by no means do such changes relate solely to the effect of "afterload" on ventricular ejection. In fact, it is probable that "preload" or venous return dominates in many circumstances. In this conceptual model, there is no rational concern regarding the decrease in stroke volume and stroke work because these are clearly appropriate for the remaining tissue (half the original) to be perfused. Decreases in cardiac functional variables should not necessarily be interpreted as "depression."

Next, consider that only the aorta is clamped. Again, this causes an acute doubling of SVR but, since venous return and cardiac output are not immediately affected, blood pressure must increase substantially. The only physiological phenomenon preventing blood pressure from doubling would be an inability of the ventricle to eject its former stroke volume against this elevated systemic resistance or, perhaps, immediate reflex feedback inhibition. Not only is venous return initially unimpeded, there is evidence that it may be increased with clamp application. Some animal studies and individual patients from clinical reports have shown an increase in cardiac output after clamping the thoracic aorta. This may be due to an "autotransfusion" of volume from the below-clamp vasculature into the active circulation. That is, blood in the capacitance vasculature below the clamp may be thought of as having an initial pressure equal to the mean systemic pressure. If arterial inflow stops at the time of aortic occlusion, the capacitance vascular below the clamp will discharge its contents into the active circulation until its pressure is equal to the right atrial pressure (or intervening vascular waterfall). This constitutes an incremental volume infusion and should serve to maintain cardiac output temporarily if the ventricle was capable of such performance in the face of the elevated afterload. Clearly the plausibility of this argument depends on maintenance of vascular tone below the clamp. If inhibition of arterial inflow continued, tissue anoxia could supervene, eventually causing relaxation of vascular tone and reuptake of volume.

Other mechanisms have been suggested to explain an increase in cardiac output with thoracic aortic clamping, including an aortic-cardiac reflex, which increases contractility, and elimination of slow time-constant vascular 
beds (splanchnic) from the circulation, and the release of neurohumeral factors. Conversely, many previous studies have shown a decreased cardiac output with aortic occlusion, and this finding has come to represent the common understanding. How is it possible to obtain such opposing results? Paradoxically, infrarenal and suprarenal cross-clamps eliminate fast time-constant vascular beds (lower extremities, kidneys) and thus could reduce cardiac output while higher thoracic clamps remove the slow time-constant visceral circulation as well, thereby tending to increase cardiac output. A complete explanation of these issues is not possible based on current published work, but interinvestigation differences in the administration of vasodilators at the time of clamp application, background anaesthesia, and intrinsic myocardial function may all play a role.

\section{Myocardial effects}

In the absence of any underlying disorder of contractility or coronary flow, the heart can generate and withstand very high arterial pressures. Although ventricular end-diastolic pressure increases in response to an elevated afterload (the "preload reserve mechanism"), coronary perfusion pressure also increases, and dysfunction of pumping characteristics or myocardial ischaemia does not occur in isolated ventricle experiments in healthy hearts. In practice, ventricular dilatation can cause valve incompetence while elevated diastolic pressures promote pulmonary oedema as the natural consequences of extreme left ventricular overload. If a high afterload is superimposed on a depressed myocardium, myocardial ischaemia itself or further failure could be precipitated. The presumed mechanism for this ischaemia is subendocardial hypoperfusion caused by the high intracavitary pressures during diastole and systole, in conjunction with impaired inflow due to stenotic coronary lesions. It seems reasonable to propose that pharmacological and mechanical interventions that control hypertension by preload reduction would be most efficacious in minimizing both dysfunction and ischae$\mathrm{mia}$ of the left ventricle. End-diastolic volume, and thus wall stress, are lower in comparison with the afterloadreducing methods, provided the same arterial blood pressure is achieved.

\section{Therapeutic strategies}

Most clinicians have viewed the physiological problem of aortic cross-clamping to be a consequence of increased left ventricular afterload and have proposed interventions that reverse this effect. Vasodilators, notably sodium nitroprusside, are routinely used to control hypertension.

Arteriolar dilatation in vessels supplying organs prox- imal to the clamp can, in most circumstances, cause them to accommodate a sufficient increase in blood flow to maintain blood pressure within an acceptable range. Obviously, this produces a relative overperfusion of the affected organs. Problems with this method include: (1) partial failure (e.g., inability to adequately control pressure), (2) requirement for high doses of sodium nitroprusside, and (3) exceedingly low pressures in the circulation distal to the lowest clamp.

Alternative strategies are suggested by the previous discussion on venous return. Venodilatation with nitroglycerine, sufficient to lower filling pressure and reduce cardiac output, appears to be the most attractive alternative. A moderate level of systemic intravascular volume depletion would be synergistic in this regard but is not recommended since declamping hypotension must be anticipated and minimized by maintenance of intravascular volume.

Bypass and shunting techniques that divert flow from the left atrium, left ventricle, or proximal aorta to the aorta distal to the lowest clamp have been used to blunt the effects of cross-clamping.

\section{Metabolic changes}

Two fundamental interconnected metabolic effects characterize aortic cross-clamping: (1) lowered total body oxidative metabolism $\left(\mathrm{VO}_{2}\right)$ and (2) conversion to anaerobic metabolism of the hypoperfused body mass distal to the clamp. The effects of aortic cross-clamping on mixed venous oxygen saturation and partial pressure depend on the therapeutic modalities used to control blood pressure. If arteriolar dilatation is the dominant therapy, then aerobically functioning tissue will be overperfused, its extraction will decrease, and the saturation and partial pressure of oxygen of mixed venous blood will increase substantially. Conversely, preload reduction techniques maintain both oxygen extraction ratio and mixed venous saturation at approximately their preclamp values.

Anaerobic metabolism by tissue below the aortic cross-clamp produces lactic acid and a progressive rise in blood lactate presumably reaching the proximal circulation by collaterals. For infrarenal cross-clamps, the buildup in systemic lactate during occlusion, as well as its release with unclamping, is noticeable but rarely clinically significant.

Cross-clamps above the coeliac axis not only produce a larger anaerobically functioning tissue mass but also, by excluding the liver and kidneys, greatly attenuate the elimination of lactate. Lactate concentration rises promptly and progressively during high thoracic crossclamps. Paradoxically, arterial blood samples taken during the cross-clamp period may not show changes in 
pH. If normocarbia was established before aortic occlusion, then maintenance of the same minute-ventilation after clamping will produce a relative hyperventilation because $\mathrm{CO}_{2}$ production has substantially diminished. This respiratory alkalosis, which is reflected by hypocarbia, can so closely balance the metabolic acidosis that $\mathrm{pH}$ will be unchanged.

\section{Renal protection}

Preservation of renal function is a primary concern during aortic aneurysm surgery. Clearly, procedures that require cross-clamping of the aorta above the renal arteries will result in a temporary period of ischaemia, with the potential for inducing some degree of renal failure. In animal experiments, preischaemia administration of mannitol exerts a protective effect on renal function. Since the mechanisms that produce acute tubular necrosis (ATN) are complex, it is not surprising that controversy exists regarding the exact manner in which mannitol or other agents might prevent ATN. It is possible that mannitol exerts its protective effect by the scavenging of free radicals produced upon reperfusion of the kidney with cross-clamp release. It is common clinical practice to administer $12.5 \mathrm{~g} \cdot 70 \mathrm{~kg}^{-1} 10$ to $15 \mathrm{~min}$ before aortic cross-clamping. The use of furosemide is more controversial. For infrarenal aneurysms, where cross-clamp application does not impede renal perfusion, it is interesting that considerable concern remains regarding postoperative renal failure. The distribution of renal blood flow is altered during infrarenal aortic cross-clamping, and this phenomenon can result in impairment of function.

Maintenance of adequate intravascular volume during the surgical procedure has been shown to be the most important factor in avoiding renal dysfunction postoperatively. Dopamine in low doses $\left(3 \mu \mathrm{g} \cdot \mathrm{kg}^{-1} \cdot \mathrm{min}^{-1}\right)$ increases renal blood flow and has other beneficial diuretic effects that make it attractive and frequently used during aneurysm surgery, especially if some element of renal dysfunction exists preoperatively. Again, clinical practice varies widely.

\section{Spinal cord ischaemia and protection}

Aortic cross-clamping, which either incorporates the Artery Radicularis Magna (ARM) between clamps or otherwise exposes it to hypoperfusion, may lead to paraplegia or paraparesis. The origin is variable, but it is uncommon for the ARM to be found lower than $L_{2}$. Low abdominal aortic aneurysm repair is associated with less than a $1 \%$ incidence of these dreaded complications. The incidence rises to $7 \%$ to $40 \%$ for thoracic and thoracoabdominal aneurysm repair. The effect of shunting or bypass techniques on spinal cord morbidity has been variable. Cunningham et al. ${ }^{3}$ reported a lower incidence of paraplegia when mean aortic blood pressure distal to the lowest clamp was maintained higher than $60 \mathrm{mmHg}$. They attributed the previously reported failure of shunts to inadequate distal pressures.

Spinal fluid drainage during aortic occlusion has been proposed by several investigators. The rationale for this procedure is based on two observations: (1) CSF pressure increases with application of an aortic clamp, and (2) the downstream pressure opposing arterial inflow to the spinal cord cannot be less than the surrounding (CSF) pressure.

As of this writing, no technique of spinal cord protection during thoracic or thoracoabdominal aneurysm repair has been sufficiently verified in clinical trials to be definitively recommended.

\section{Unclamping}

Release of the aortic cross-clamp results in metabolic and haemodynamic changes that vary in magnitude according to (1) the extent and nature of the tissue reperfused, (2) the total occlusion time, (3) administration of fluids and therapeutic agents during the crossclamp period and at the moment of unclamping, and (4) the use of shunts or bypass. The most consistent observation of cardiovascular behaviour on clamp release in the absence of shunts or bypass is an acute decrease in systemic blood pressure. The dominant influence is a decrease in SVR due to opening of the previously minimally perfused vascular beds. The latter, in turn, may be maximally dilated due to reactive hyperaemia. Release of an infrarenal clamp usually causes a small decrease in blood pressure that is transient and well tolerated although treatment with fluid infusion or small increments of a vasopressor occasionally may be necessary. Removal of a supracoeliac cross-clamp can result in profound hypotension, which (1) should be anticipated by vigorous prerelease intravascular volume administration and (2) frequently requires transient vasopressor support.

Other mediators have been implicated in unclamping hypotension. Myocardial depressant factors have been circumstantially proposed but never specifically identified. Acidosis may be considerable (see below) and could contribute to myocardial depression and systemic vasodilatation.

Total body oxygen consumption increases with unclamping as below-clamp tissues return to aerobic metabolism. Mixed venous blood shows an abrupt desaturation within minutes after release of a supracoeliac clamp and rapidly returns to preclamp values.

Carbon dioxide is elevated in arterial and venous blood within moments of unclamping, and this is 
reflected in the end-tidal partial pressure. Two principal sources contribute to the appearance of $\mathrm{CO}_{2}$ : (1) as the end-product of aerobic metabolism, and (2) from the buffering (through carbonic acid) of organic acids that are washed out during reperfusion. The rise in $\mathrm{PaCO}_{2}$ eliminates the respiratory alkalosis that had stabilized $\mathrm{pH}$ during aortic occlusion (see previous section on metabolic changes) and peaks with the bolus of lactic acid to produce a clinically important increase in hydrogen ion concentration. It was formerly common clinical practice to administer a bolus of sodium bicarbonate just before unclamping in an attempt to buffer the expected decrease in $\mathrm{pH}$. Unfortunately, additional $\mathrm{CO}_{2}$ produced by the exogenous bicarbonate buffering adds to the $\mathrm{CO}_{2}$ produced by aerobic metabolism grossly increases $\mathrm{PaCO}_{2}$. Carbon dioxide readily diffuses across cell membranes and could worsen intracellular acidosis, resulting in organ dysfunction (e.g., cardiac conduction and contractility disturbances). Bicarbonate should be administered, if desired, during occlusion, well before unclamping.

Lactate increases measurably on release of an infrarenal clamp, but the change is clinically irrelevant. Supracoeliac unclamping produces an additional increase of $3.6 \mathrm{mmol} \cdot \mathrm{L}^{-1}$ for a mean clamp time of 45 min. Longer occlusion periods result in higher concentrations. Lactate concentrations rapidly return to normal after complete restoration of hepatic and liver flow and elimination of continued excess production. It is uncommon for significant lactate elevation to persist into the postoperative period.

\section{Postoperative care}

It is generally conceded that control of the stress response is necessary to reduce the incidence of postoperative cardiac morbidity. Since pain is a major component of stress, its alleviation is an important part of postoperative management considerations. Surgeons and intensivists seem to be gaining an appreciation of this issue. At one extreme, patients may be given large doses of opioids with sedative supplementation and planned overnight ventilation, as is commonly done after coronary artery bypass grafting. This approach may be associated with a smoother course for both the intensive care staff and the patient for as long as sedation is maintained. Weaning from mechanical ventilation, of course, must eventually occur, and this begins a period of delicate balance between adequate analgesia for both the surgical incision and presence of the endotracheal tube and too much sedation, causing respiratory depression. However, the stress of weaning from ventilatory support may be detrimental to the patient with coronary artery disease. The need for continued mechanical ventilation must be considered for each individual case, taking into account the risks and benefits of each alternative.

Several authors have recommended the use of epidural opioids or local anaesthetics as adjuncts to postoperative pain relief in aneurysm patients. One investigation showed that the preoperative administration of morphine $\left(0.1 \mathrm{mg} \cdot \mathrm{kg}^{-1}\right)$ in the epidural space resulted in considerably lower levels of epinephrine, norepinephrine, and arterial blood pressure in the postoperative period. In some of these patients the tracheas were extubated and in some they were not. Another study using a small number of patients has shown that epidural opioids may also reduce the incidence of postoperative tachycardia, ventricular ectopy, and, possibly, cardiac ischaemia. Conversely, two recent investigations, one using aneurysm surgery and the other using major upper abdominal surgery (including aneurysm repair) found no difference in morbidity or mortality rates when pure, general anaesthesia was compared with a combined regional/general technique.

\section{References}

1 Hertzer NR, Bevan EG, Young JR, et al. Coronary artery disease in peripheral vascular patients. A classification of 1000 coronary angiograms and results of surgical management. Ann Surg 1984; 199: 223-33.

2 Fleisher LA, Skolnick ED, Holroyd KJ, Lehmann HP. Coronary artery revascularization before abdominal aortic aneurysm surgery: a decision analytic approach. Anesth Analg 1994; 79: 661-9.

3 Cunningham JN Jr, Laschinger JC, Spencer FC. Monitoring of somatosensory evoked potentials during surgical procedures on the thoracoabdominal aorta. IV. Clinical observations and results. J Thorac Cardiovasc Surg 1987; 94: 275-85.

4 Gelman $S$. The pathophysiology of aortic cross-clamping and unclamping. Anesthesiology 1995; 82: 1026-60.

5 Beattie C, Frank SM. Anesthesia for major vascular surgery. In: Rogers MC, Tinker JH, Covino BG, Longnecker DE (Eds.). Principles and Practice of Anesthesiology. St. Louis: CV Mosby, 1992: 1931-67. 


\title{
L'anesthésie pour la chirurgie vasculaire majeure
}

\author{
Charles Beattie PhD MD
}

Les objectifs de cette conférence d'actualisation seront : 1) de renseigner sur l'historique, l'évaluation préopératoire et sur l'appréciation du risque chez des patients programmés pour une chirurgie vasculaire majeure; 2) réviser certains aspects essentiels de la physiologie et de la physiopathologie du clampage aortique; et 3 ) résumer nos connaissances sur l'efficacité des différentes techniques anesthésiques utilisées pour ces interventions.

\section{L'évaluation préopératoire, l'évaluation et la modification du risque}

Comme les patients qui se présentent une chirurgie vasculaire majeure sont ordinairement athéroscléreux, la plupart d'entre eux auront des manifestations évidentes ou au moins occultes de maladies vasculaires intéressant plusieurs systèmes. L'étude classique de Hertzer et al. ${ }^{1}$ a démontré qu'une très grande proportion des patients soumis à une chirurgie de l'aorte souffraient d'au moins une sténose coronaire importante. Un consensus général sur cette réalité a été à l'origine d'une grande variété de pratiques cliniques concernant le nombre et la nature des épreuves préopératoires chez ces patients. La dernière décennie a été témoin d'intenses recherches visant à évaluer les épreuves préopératoires (dipyridamole-thallium, ECG ambulatoire, échographie au stress, etc.) qui permettent d'identifier les patients à risque de morbidité et de mortalité cardiaque avec un très haut degré de sensibilité et de spécificité. À l'inverse, on s'est beaucoup moins intéressé au difficile problème de la définition d'une séquence d'examens appropriée pour le bilan préopératoire et le traitement visant à minimiser le risque déjà déterminé. L'évaluation du risque n'aura de la valeur que si elle réussit à le modifier, ou si elle influence les décisions qui entourent les interventions chirurgicales et anesthésiques. Très récemment, on a commencé des travaux qui permettront d'insérer ce sujet dans une perspective plus rationnelle. Fleisher et al., ${ }^{2}$ ont publié une approche analytique décisionnelle permettant de diriger la conduite et le traitement avant une chirurgie de l'anévrisme de l'aorte abdominale. Cette étude montre que la décision de réaliser certaines épreuves particulières (qui pourraient mener à une chirurgie de l'artère coronaire ou à un autre traitement avant la chirurgie vas- culaire planifiée) dépend de plusiẹurs éléments de données qui concernent la morbidité et la mortalité et qui sont spécifiques à chaque institution. Ceux-ci comprennent : 1) le taux usuel de mortalité cardiaque pour la chirurgie de l'anévrisme de l'aorte abdominale; 2) le taux de mortalité pour la revascularisation coronaire; 3) le taux de mortalité cardiaque en rapport avec la chirurgie anévrismale chez des patients qui ont subi une chirurgie de revascularisation coronaire; 4) la probabilité d'une insuffisance coronaire chez les patients qui ont une symptomatologie particulière; 5) la mortalité cardiaque en rapport avec la chirurgie anévrismale chez les patients qui ont une maladie coronaire mal contrôlée; 6) le taux de mortalité de l'angiographie coronaire; 7) le taux de mortalité cardiaque en rapport avec la chirurgie de l'anévrisme abdominal réalisée sans épreuves complémentaires ni revascularisation myocardique; et 8) la sensibilité et la spécificité de l'épreuve demandée. Évidemment, comme ces données varient d'une institution à une autre et même à l'intérieur d'une même institution, à différents moments ou entre différentes équipes, le rendement réel des différentes épreuves diagnostiques dépend de plusieurs facteurs.

Dans les institutions dont la mortalité cardiaque consécutive à la chirurgie anévrismale est moins de 7,5\% chez les insuffisants coronariens dont la maladie est mal contrôlée, les épreuves préopératoires n'amélioreront pas les résultats quelque soit la probabilité d'insuffisance coronaire pour cette population. Cette conclusion est très importante pour deux raisons : 1) parce son implantation systématique aura pour effet de diminuer considérablement les moyen utilisés pour l'investigation et par conséquent les coûts hospitaliers en général; 2) parce qu'elle démontre la très grande portée des détails de la gestion périopératoire, susceptibles d'influencer positivement la morbidité générale.

L'influence que pourrait exercer le monitorage sur les résultats mérite notre attention. D'abord, toutes des interventions chirurgicales sur l'aorte nécessitent la mise en place d'un monitorage intravasculaire continu de la pression artérielle. Bien que certains cliniciens favorisent l'installation d'un cathéter de Swan-Ganz chez tous les patients soumis à un clampage aortique, d'autres basent leur décision sur le niveau du clampage 
et la gravité des affections associées. Il semble rationnel d'installer un cathéter de Swan-Ganz avant un clampage suprarénal (ou plus élevé) et de réserver son utilisation aux cas d'anévrismes infrarénaux ou de maladie occlusive chez ceux dont l'atteinte cardiaque, rénale ou pulmonaire est importante. Pour la chirurgie anévrismale, il ne fait aucun doute que les changements rapides du volume intravasculaire associés aux problèmes postopératoires causés par la mobilisation des liquides et la dysfonction rénale, justifient l'usage des cathéters artériels pulmonaires chez tous les patients à l'exception peutêtre des plus robustes. Il faut s'assurer toutefois que ce monitorage est mis en marche en toute sécurité; que les transducteurs de pression sont au niveau, calibrés et remis à zéro; que la technique de mesure du débit cardiaque est valide; que les variables calculées et mesurées sont interprétées correctement; et que les interventions thérapeutiques sont conformes à la physiologie et à la pharmacologie. S'il manque une seule de ces conditions, il vaut mieux s'abstenir d'utiliser le cathéter de Swan-Ganz. Comme le maniement efficace et approprié des données fournies par ce cathéter dépend de l'ensemble des facteurs mentionnés plus haut, il devient pratiquement impossible d'établir sans équivoque la valeur de cette intervention. Entre les mains de ceux qui ont acquis la compétence nécessaire, le cathéter de Swan-Ganz devient un outil de grande valeur.

On assume sans l'avoir prouvé, que, pour réduire la morbidité et la mortalité, il est important de maintenir une perfusion systémique adéquate au cours de la période périopératoire. Sur la base de nos connaissances actuelles, on peut aussi affirmer que les objectifs de l'anesthésie devraient comprendre l'atténuation ou même la l'interruption de la réponse au stress chirurgical. Parmi les effets bénéfiques de la réduction de la réponse au stress, il faut surtout mentionner la diminution d'hypercoagulabilité périopératoire, la préservation de la fonction immunitaire, et la réduction probable de l'ischémie myocardique.

\section{Physiologie et physiopathologie du clampage aortique}

Les altérations hémodynamiques et métaboliques provoquées par l'interruption subite du débit sanguin aortique se manifestent par des changements de pression artérielle, de la fonction cardiaque, de la perfusion myocardique et de l'équilibre-acido-basique et mettent en danger l'intégrité tissulaire des reins, des viscères et de la moelle épinière.

\section{La pression artérielle}

Le degré d'hypertension provoquée par le clampage de l'aorte dépend du site de clampage, du degré de col- latéralisation et du débit aortique avant l'occlusion. Ainsi, un clampage infrarénal chez le porteur d'une maladie aortique occlusive peut ne provoquer aucune augmentation de la pression artérielle parce que le débit préclampage était nul. Le clampage réalisé plus bas que les artères rénales est le plus fréquent et ne produit ordinairement qu'une petite augmentation de la pression artérielle alors que l'occlusion supracoeliaque risque de provoquer une poussée hypertensive extrême.

\section{Retour veineux et débit cardiaque}

Bien qu'intuitivement on puisse penser que le débit cardiaque diminuera avec l'occlusion subite d'un conduit artériel majeur par augmentation de la résistance, la situation est beaucoup plus complexe à cause des mécanismes réflexes, du retour veineux et du fonctionnement du coeur gauche. Pour fin d'illustration, imaginons d'abord que le débit artériel et le retour veineux qui alimentent la perfusion sous-diaphragmatique sont coupés simultanément (en d'autres mots, que l'aorte thoracique descendante et la veine cave inférieure sont toutes deux clampées). Le débit cardiaque devrait alors diminuer immédiatement de moitié étant donné que la moitié du retour veineux a été éliminée. Pendant ce temps, le lit artériel n'a plus que la moitié des vaisseaux pour recevoir le débit; en conséquence, sa résistance doublera. Lorsque la moitié du débit cardiaque fait face à une résistance doublée, la pression artérielle ne change pas. Dans ce scénario, le volume systolique et le travail systolique ont aussi été diminués de moitié. Ceci illustre un point majeur concernant les changements directionnels des variables hémodynamiques pendant le clampage de l'aorte : de tels changements ne dépendent pas uniquement de l'effet de la postcharge sur l'ejection ventriculaire. En réalité, il est probable que la précharge ou le retour veineux soit le facteur dominant dans plusieurs circonstances. Dans ce modèle de concept, on n'a pas raison de s'inquiéter de la diminution du volume systolique et du travail systolique parce qu'ils sont clairement appropriés au tissus résiduel (la moitié du tissu original) qu'il faut perfuser. La baisse des variables cardiaques fonctionnelles ne doit pas nécessairement être interprétée comme une défaillance.

Maintenant, présumons que seule l'aorte est clampée. Encore là, ceci double la résistance vasculaire systémique mais comme le retour veineux et le débit cardiaque ne sont pas immédiatement affectés, la pression artérielle doit s'élever de façon substantielle. Le seul phénomène physiologique susceptible d'empêcher la pression artérielle de doubler serait l'incapacité du ventricule à éjecter son volume systolique original contre une résistance systémique augmentée ou l'inhibition immédiate possible du réflexe de rétroaction. Au début, 
non seulement le retour veineux ne rencontre pas d'obstacle, mais il est démontré qu'il peut augmenter après l'application du clamp. Certaines études animales et certaines observations cliniques ont révélé une augmentation du débit cardiaque après le clampage de l'aorte thoracique. Ceci peut être dû à une autotransfusion dans la circulation active du volume sanguin intravasculaire situé sous le clamp. En d'autre mot, c'est comme si le sang contenu dans les vaisseaux de capacitance situés sous le clamp avait une pression initiale égale à la pression systémique moyenne. Si l'arrivée du sang artériel cesse au moment de l'occlusion aortique, les vaisseaux de capacitance situés sous le clamp se vident de leur contenu dans la circulation active jusqu'à ce que la pression soit égale à la pression de l'oreillette droite (l'effet de la chute d'eau vasculaire). Ceci constitue une perfusion progressive et devrait servir temporairement au maintien du débit cardiaque si le ventricule est capable de conserver son efficacité devant une postcharge élevée. Cet argument n'est plausible que si le tonus vasculaire sous le clamp est conservé. Si l'arrivée de sang artériel continue d'être inhibée, l'anoxie tissulaire prend le dessus et provoque éventuellement une relaxation du tonus vasculaire avec recaptage volumique.

On a suggéré d'autres mécanismes pour expliquer l'augmentation du débit cardiaque par clampage de l'aorte thoracique dont le réflexe aorto-cardiaque qui augmente la contractilité, l'élimination de la circulation des lits vasculaires à constante de temps lente (splanchnique), et la libération de facteurs neurohuméraux. D'autre part, plusieurs études antérieures ont déjà montré que débit cardiaque diminuait après l'occlusion aortique et cette constatation a fini par prédominer dans l'opinion générale. Comment peut-on d'obtenir des résultats si divergents? Paradoxalement, le clampage infrarénal et suprarénal élimine les lits vasculaires à constance de temps rapide (les extrémités inférieures, les reins) et pourraient ainsi réduire le débit cardiaque alors que les clamps thoraciques situés plus haut éliminent en même temps la circulation viscérale à constante de temps lente, ce qui a tendance à augmenter le débit cardiaque. Les travaux publiés jusqu'à maintenant ne peuvent fournir de réponse complète à ces questions mais il semble que les disparités entre ces résultats soient causées par des différences portant sur l'administration de vasodilatateurs au moment de l'application du clamp, de l'anesthésie utilisée et de la fonction intrinsèque du myocarde.

\section{Les effets myocardiques}

En absence de toute anomalie préalable de contractilité ou de débit coronaire, le coeur peut générer et supporter de très hautes pressions artérielles. Bien que la pression télédiastolique ventriculaire augmente en réponse à une élévation de la postcharge (le mécanisme « de réserve de la précharge »), la pression de perfusion coronaire augmente elle aussi. Le dysfonctionnement de la pompe et l'ischémie coronaire ne surviennent pas au cours d'expérience sur des ventricules isolés de coeurs sains. En pratique, la dilatation ventriculaire peut provoquer une incompétence valvulaire alors que l'augmentation des pressions diastoliques favorise l'oedème pulmonaire, conséquence d'une surcharge ventriculaire gauche extrême. Si on impose une postcharge additionnelle à un myocarde déprimé, l'ischémie myocardique et l'insuffisance cardiaque s'aggravent. Cette ischémie est présumée causée par une hypoperfusion sous-endocardique provoquée par l'augmentation des pressions intracavitaire pendant la diastole et la systole, en association avec la détérioration du débit coronaire consécutive à une sténose. Les interventions pharmacologiques et mécaniques qui contrôlent l'hypertension en diminuant la précharge sont plus susceptibles de minimiser le dysfonctionnement et l'ischémie ventriculaires gauches. Le volume télé-diastolique, ainsi que le stress pariétal sont moins élevés en comparaison avec les méthodes qui visent à diminuer la postcharge en autant que le même niveau de pression artérielle est atteint.

\section{Stratégies thérapeutiques}

La plupart des cliniciens considèrent que le problème physiologique causé par le clampage est une conséquence de l'augmentation de la postcharge ventriculaire gauche et ont proposé des interventions à ce niveau. Les vasodilatateurs, notamment le nitroprussiate de soude, sont utilisés régulièrement pour contrôler l'hypertension.

La dilatation artériolaire des vaisseaux qui alimentent les organes situés à proximité du clamp peut dans la plupart des circonstances leur permettre de recevoir une augmentation suffisante du débit sanguin pour maintenir la pression artérielle dans des limites acceptables. De toute évidence, ceci produit une surperfusion relative des organes affectés. Les problèmes causés par cette méthode sont : 1) l'échec partiel (par exemple, l'incapacité de contrôler la pression de façon adéquate); 2) la nécessité d'administrer des doses élevées de nitroprussiate de soude, et 3 ) des pressions très basses dans la circulation distale au clampage.

On peut faire appel à d'autres stratégies pour intervenir sur le retour veineux. Parmi celles-ci, la dilatation veineuse par la nitroglycérine, en dose suffisante pour abaisser la pression de remplissage et réduire le débit cardiaque, semble être la plus attrayante. Un niveau modéré d'hypovolémie pourrait renforcer cet effet mais 
il n'est pas recommandé étant donné qu'il faut anticiper l'hypotension au déclampage et l'atténuer par le maintien du volume intravasculaire. Des techniques de shunt et de dérivation qui détournent le débit à partir de l'oreillette gauche, du ventricule gauche ou de l'aorte proximale vers l'aorte distale ont été utilisés pour amortir cet effet du clampage.

\section{Les changements métaboliques}

Deux effets métaboliques conjugués caractérisent le clampage aortique : 1) une baisse du métabolisme oxydatif total $\left(\mathrm{VO}_{2}\right)$ et 2$)$ la conversion à un métabolisme anaérobie de la masse corporelle hypoperfusée distale au clamp. Les effets du clampage aortique sur la saturation du sang veineux mêlé et la pression partielle en oxygène dépend des interventions thérapeutiques utilisées pour contrôler la pression artérielle. Si la dilatation artériolaire constitue la principale méthode, les tissus fonctionnant en aérobie seront surperfusés, l'extraction de l'oxygène diminuera et la saturation et la pression partielle de l'oxygène dans le sang veineux mêlé augmenteront substantiellement. Au contraire, les techniques de réduction de la précharge maintiennent à la fois le rapport d'extraction de l'oxygène et la saturation du sang veineux mêlé près des valeurs préclampage.

Le métabolisme anaérobie des tissus situés sous le clampage produit de l'acide lactique et une augmentation progressive du lactate plasmatique qui atteint la circulation proximale par les collatérales. Pour les clampages infrarénaux, l'augmentation de l'accumulation du lactate systémique pendant l'occlusion ainsi que sa libération avec le déclampage est perceptible mais rarement significative cliniquement.

Le clampage au-dessus du tronc coliaque isole non seulement une masse tissulaire fonctionnant en anaérobie mais aussi en excluant le foie et les reins atténue considérablement l'élimination du lactate. La lactasémie augmente rapidement et progressivement pendant le clampage thoracique haut situé. Paradoxalement, les échantillons de gaz artériel prélevés pendant la période de clampage peuvent ne pas montrer de changement de pH. Si une normocarbie a été établie avant l'occlusion aortique, le maintien de la même ventilation/minute après le clampage produira une hyperventilation relative parce que la production de $\mathrm{CO}_{2}$ aura beaucoup diminué. L'alcalose respiratoire, qui est le reflet de l'hypocarbie, peut compenser l'acidose métabolique de très près de sorte que le $\mathrm{pH}$ demeurera inchangé.

\section{La protection rénale}

En chirurgie anévrismale aortique, il faut se préoccuper tout particulièrement de la préservation de la fonction rénale. Le clampage de l'aorte au-dessus des artères rénales provoquera une période d'ischémie transitoire avec la possibilité d'insuffisance rénale subséquente. Chez l'animal, l'administration de mannitol avant l'ischémie protège la fonction rénale. Le mécanisme de la nécrose tubulaire aiguë étant très complexe, la controverse qui subsiste sur le mode d'action du mannitol ou d'autres substance n'a rien de surprenant. Il est possible que le mannitol exerce son effet protecteur en récupérant les radicaux libres libérés au moment de la reperfusion du rein une fois le clamp relâché. L'administration de mannitol $12,5 \mathrm{~g} \cdot 70 \mathrm{~kg}^{-1}, 10$ ou 15 minutes avant le clampage aortique est une pratique très répandue. L'utilisation de la furosémide est plus controversée. En ce qui concerne les anévrismes infrarénaux, où l'application du clamp n'a pas d'effet sur la perfusion rénale, c'est plutôt l'insuffisance rénale postopératoire qui est la plus préoccupante. La distribution du débit sanguin rénal est altérée au cours du clampage aortique intrarénal et ce phénomène peut provoquer une détérioration de la fonction rénale.

Il a été démontré que, pendant l'intervention, le maintien d'un volume intravasculaire adéquat représentait le facteur le plus important en ce qui concerne la prévention du dysfonctionnement rénal postopératoire. La dopamine à faible dose $\left(3 \mu \mathrm{g} \cdot \mathrm{kg} \cdot \mathrm{min}^{-1}\right)$ augmente le débit sanguin rénal et procure une diurèse bénéfique, ce qui explique son attrait et motive son utilisation pendant la chirurgie anévrismale, surtout s'il existait antérieurement une atteinte rénale. Cette pratique ne fait toutefois pas l'unanimité.

\section{L'ischémie et la protection de la moelle épinière}

Un clampage qui inclut la grande artère radiculaire (Adamkiewicz) ou qui l'expose à l'hypoperfusion peut mener à la paraparésie et à la paraplégie. Le point d'origine de cette artère varie, mais il n'est pas rare de le trouver sous $\mathrm{L}_{2}$. La réparation d'un anévrisme aortique bas situé est associée avec une incidence de cette tragique complication inférieure à $1 \%$. L'incidence s'élève de $7 \%$ à $40 \%$ pour les réparations d'anévrisme thoracique ou thoraco-abdominal. Le rôle des techniques de shunt et autres dérivations sur les lésions de la moelle épinière est incertain. Cunningham $e t a l .^{3}$ rapportent une incidence plus faible de paraplégie quand la pression moyenne aortique distale au clamp le plus bas situé est maintenu au-dessous de $60 \mathrm{mmHg}$. Ils attribuent les échecs du shunt déjà rapportés à des pressions d'aval insuffisantes.

Le drainage rachidien pendant l'occlusion aortique a été proposé par plusieurs auteurs. Leur raisonnement est basé sur deux observations : 1) la pression du LCR augmente avec le clampage aortique, et 2) la pression d'aval qui s'oppose à l'arrivée du sang artériel à la 
moelle épinière ne doit pas être inférieure à la pression du LCR.

Jusqu'à maintenant aucune technique de protection médullaire applicable à la réparation de l'anévrisme thoracique ou thoraco-abdominal a été suffisamment éprouvée au cours d'essais cliniques pour mériter une recommandation définitive.

\section{Le déclampage}

Le déclampage de l'aorte provoque des changements métaboliques et hémodynamiques qui varient d'intensité selon : 1) l'étendue et la morphologie des tissus reperfusés; 2) la durée totale de l'occlusion; 3) l'administration de liquides et d'agents thérapeutiques pendant la période de clampage et au moment du déclampage, et 4) l'utilisation de shunt ou dérivation. En absence de shunt ou de dérivation, l'incident le plus souvent noté au déclampage est une chute subite de la pression systémique. Cette chute de pression survient principalement à cause de la diminution de la résistance vasculaire périphérique provoquée par l'ouverture de lits vasculaires qui étaient auparavant très peu perfusés. Ces lits vasculaires peuvent à leur tour se dilater au maximum par hyperémie réactive. L'ouverture d'un clamp infrarénal entraîne souvent une faible baisse de la pression transitoire et bien tolérée quoique il soit occasionnellement nécessaire de la traiter avec des perfusions de liquide ou des petites doses de vasopresseurs. L'ouverture d'un clamp supracoeliaque peut causer une hypotension profonde qui : 1) devrait être anticipée par un remplacement vasculaire vigoureux, et 2) nécessite fréquemment l'administration d'un vasopresseur.

D'autres médiateurs ont été impliqués dans l'hypotension du déclampage. Des facteurs susceptible de déprimer le myocarde ont été proposés à l'occasion mais jamais spécifiquement identifiés. L'acidose peut être considérable et peut contribuer à la dépression myocardique et à la vasodilatation systémique.

Au déclampage, lorsque les tissus en aval du clamp reviennent a l'aérobie, la consommation totale en oxygène augmente. Le sang veineux mêlé se désature rapidement en quelques minutes après le relâchement d'un clamp supracoeliaque et retourne rapidement aux valeurs d'avant le déclampage. Immédiatement après le déclampage, le gaz carbonique s'élève dans le sang artériel et veineux et ceci se reflète sur la pression partielle télé-expiratoire. Deux sources principales contribuent à l'augmentation du $\mathrm{CO}_{2}$ dans la circulation : 1) la dégradation du métabolisme aérobie dont il est le produit final et 2) le tamponnement par l'acide carbonique des acides organiques qui circulaient pendant la reperfusion. L'augmentation du $\mathrm{CO}_{2}$ neutralise l'alcalose respiratoire qui avait stabilisé le $\mathrm{pH}$ pendant l'occlusion de l'aorte et atteint son pic avec le bolus d'acide lactique pour produire une augmentation cliniquement importante de la concentration en ions hydrogènes. Il a déjà été pratique courante d'administrer un bolus de bicarbonate de soude immédiatement avant le déclampage dans le but de tamponner la baisse anticipée du $\mathrm{pH}$. Malheureusement, ce $\mathrm{CO}_{2}$ additionnel produit par le bicarbonate exogène s'ajoute au $\mathrm{CO}_{2}$ produit par le métabolisme aérobie et augmente la $\mathrm{PaCO}_{2}$ de façon exagérée. Le gaz carbonique diffuse rapidement à travers les membranes cellulaires et pourraient aggraver l'acidose intracellulaire et provoquer du dysfonctionnement organique (par exemple, un dérèglement de la conduction cardiaque et de la contractilité). Si on désire administrer du bicarbonate, il faut le faire pendant l'occlusion bien avant le déclampage.

Le lactate augmente de façon importante au moment de l'ouverture d'un clamp infrarénal mais ce changement n'a cliniquement pas d'importance. Le déclampage supracoeliaque produit une augmentation additionnelle de $3,6 \mathrm{mmol} \cdot \mathrm{L}^{-1}$ pour une durée moyenne de clampage de 45 minutes. Des durées d'occlusion plus longues produisent des concentrations plus élevées. La concentration de lactate retourne rapidement à la normale une fois le débit sanguin hépatique restauré et les causes de la production exagérée éliminées. L'augmentation du lactate persiste rarement à la période postopératoire.

\section{Soins postopératoires}

Il est généralement reconnu que le contrôle de la réponse au stress est nécessaire pour diminuer l'incidence de la morbidité cardiaque postopératoire. Comme la douleur est une composante majeure du stress, son soulagement représente un aspect important de la gestion postopératoire. Les chirurgiens et les intensivistes semblent maintenant reconnaître ce problème. On peut administrer des fortes doses de morphiniques auxquelles on ajoute des sédatifs et planifier la ventilation pour la nuit comme on le fait fréquemment après une chirurgie de revascularisation coronaire. Cette approche peut être associée à une évolution moins tumultueuse tant pour le personnel de l'unité des soins intensifs que pour le patient aussi longtemps que la sédation est maintenue. Il faudra éventuellement sevrer le patient de la ventilation mécanique. Mais auparavant commence une période d'équilibre délicat entre l'analgésie requise autant pour soulager la douleur de la plaie chirurgicale que pour permettre de tolérer le tube endotrachéal, et une sédation exagérée qui déprime la respiration. Cependant, le stress du sevrage ventilatoire peut être néfaste au patient qui souffre d'insuffisance coronaire. Le besoin de ventilation mécanique continuelle doit être considéré pour 
chaque cas individuellement en tenant compte des risques et des bénéfice de chacune des méthodes.

Plusieurs auteurs ont recommandé d'administrer des morphiniques et des anesthésiques locaux par la voie épidurale comme thérapie d'appoint pour le soulagement de la douleur postopératoire chez les opérés pour un anévrisme. Une étude a montré que l'administration préopératoire de morphine $\left(0,1 \mathrm{mg} \cdot \mathrm{kg}^{-1}\right)$ par l'espace épidural diminuait considérablement, à la période postopératoire, les concentrations plasmatiques d'épinéphrine, de norépinéphrine et la pression artérielle. On a extubé certains de ces patients alors que d'autres sont demeurés intubés. Une autre étude portant sur un petit nombre de patients a montré que les morphiniques épiduraux peuvent aussi réduire l'incidence de la tachycardie postopératoire, de l'ectopie ventriculaire et, possiblement, de l'ischémie myocardique. D'autres part, deux études récentes, dont une portait sur la chirurgie anévrismale et l'autre sur une chirurgie majeure de l'abdomen supérieur (incluant la réparation anévrisme) n'ont pas trouvé de différence en ce qui concerne la morbidité et/ou la mortalité quand une anesthésie générale pure était comparée à une technique combinée régionale-générale.

\section{Références}

(Voir page R7) 